\title{
SOCIAL ENTREPRENEURSHIP AND CLASSICAL ENTREPRISE WITH SOCIAL RESPONSIBILITY ANALYSIS: ADVANTAGES AND DISADVANTAGES
}

\author{
Pereverzieva A.V., Osaul A.O., Havrylova K.O. \\ Zaporizhzhia National University \\ Ukraine, 69600, Zaporizhzhia, Zhukovsky str., 66. \\ pereverzeva@ukr.net, alinaosaul@ukr.net,katya-zp@ukr.net \\ ORCID 0000-0001-8391-6636, ORCID 0000-0002-5194-9799
}

Key words:

integration, social entrepreneurship, social business, classical entrepreneurship, development, responsibility, society, trend.
The article is devoted to the study of the concept of "social entrepreneurship" and "social business" amid rapid development and integration of classical entrepreneurship, its basic principles and business models. The authors identify the role of social issues and society as a motivating factor for the creation of social enterprises. Theoretical interpretation of the concepts of "traditional enterprise with social responsibility", "social entrepreneurship", "social business" has been given. The importance of business social responsibility and cooperation with social enterprises has been outlined. Based on the comparative analysis, the main differences and common features of a classic enterprise with social responsibility and social entrepreneurship have been identified. This allowed to highlight the advantages and disadvantages of each form of management. The world trend of social entrepreneurship development and the importance of introducing social responsibility for businesses have been determined. Five opportunities for the development of social entrepreneurship in Ukraine have been studied. It has been proved that the lack of social entrepreneurship regulatory framework is an obstacle to the development of social entrepreneurship and its consolidation as an innovative form of management. Analysis of the best country for the development of social entrepreneurship has been provided and the leading countries in the development of the form of management with social guidelines have been identified. It has been proved that the main objective of social entrepreneurship is to solve the problems of society, which is a priority in the activity, and to obtain certain benefits.

\section{АНАЛІЗ СОЦІАЛЬНОГО ПІДПРИЄМНИЦТВА ТА КЛАСИЧНОГО ПІДПРИСМСТВА З СОЦААЛЬНОЮ ВІДПОВІДАЛЬНІСТЮ: ПЕРЕВАГИ ТА НЕДОЛІКИ}

\author{
Переверзсва А.В., Осаул А.О., Гаврилова К. \\ Запорізький національний університет \\ Україна, 69600, м. Запоріжжя, вул. Жуковського, 66
}

\begin{abstract}
Ключові слова:
інтеграція, соціальне підприємництво, соціальний бізнес, класичне підприємництво, розвиток, відповідальність, соціум, тенденція.
\end{abstract}

Стаття присвячена дослідженню поняття «соціальне підприємництво» та «соціальний бізнес» через стрімкий розвиток та інтеграцію класичного підприємництва, основним принципам та бізнес-моделям. Авторами визначено роль соціальних проблем та соціуму як спонукального чинника створення соціальних підприємств. Надано теоретичне трактування понять «традиційне підприємство 3 соціальною відповідальністю», «соціальне підприємництво», «соціальний бізнес». Окреслено значимість соціальної відповідальності підприємств та співпраці бізнесу 3 соціальними підприємствами. На основі порівняльного аналізу визначено головні відмінності та спільні риси класичного підприємства 3 соціальною відповідальністю та соціального підприємництва, що дозволило виокремити переваги та недоліки кожної форми господарювання. Визначено світову тенденція розвитку соціального підприємництва та важливість впровадження соціальної відповідальності для бізнесу. Досліджено п'ять можливостей для розвитку соціального підприємництва в Україні. Обгрунтовано, що відсутність нормативно-правової бази регулювання соціального підприємництва $\epsilon$ перешкодою розвитку соціального підприємництва та іiі закріплення як інноваційної форми господарювання. Проаналізовано дослідження щодо найкращої країни для розвитку соціального підприємництва та визначено країн-лідерів із розвитку форми господарювання з соціальними орієнтирами. Доведено, що головною метою функціонування соціального підприємництва $є$ вирішення проблем соціуму, що $є$ пріоритетним у діяльності, та отримання певної вигоди. 


\section{Statement of the problem}

Nowadays the issues referring people with disabilities, environmental disasters, vulnerable populations, inclusion, domestic tourism, animal protection, organic production, healthy nutrition, access to education, qualified medical care are taken into consideration simultaneously with the common issues of corruption, unemployment, hunger, domestic producers and local markets support, inflation, compulsion, racism, equality of rights and freedoms. The topic of inclusion has become relevant for the last 10 years, and it has become the social vector in the international public policies and business models. According to the 17 goals of the UN sustainable development the results of all implemented processes are aimed at the well-being and happy future for the next generations. Taking into account the Asian principle of entrepreneurship, one can say that many centuries ago they realized that the main resource is a person, who creates problems and does everything possible to solve them, as well as tries his/her best for the comfortable life.

\section{Analysis of recent studies and publications}

Social entrepreneurship is the subject of research of both foreign and Ukrainian scholars. M.V. Konovalova, O.M. Kharinina [1], T.I. Lunkina, G. Yu. Ivanenko [2], O.O. Kozhemyachenko, O.S. Solosich, M.O. Holub [3], N.M. Horishna [4], M.D. Pryshchak, O.Y. Lesko [5] among other Ukrainian scientists paid considerable attention to the study of theoretical and practical aspects of social enterprises' functioning and development. Scientists traditionally study and apply the concept of "social entrepreneurship", justify the feasibility of doing business and its further development to reduce the uncertainty and risk amid increasing global trends.

\section{Objectives of the article}

The study objective is a theoretical definition of the concept of "social entrepreneurship", distinguishing of its features in comparison with other forms of management in order to determine the possibilities of its development intensification in the national economy.

\section{The main material of the research}

The definition of the concept of "social entrepreneurship", distinguishing of its features in comparison with other forms of management, requires understanding of certain categories, such as: the classical model of entrepreneurship, social business, social entrepreneurship.

We specify the essence of the above economic categories:

- the classical model of entrepreneurship characterizes the behaviour of the entrepreneur aimed at obtaining the maximum return on available resources. The average entrepreneur can make the same product for many years, perhaps even following an out-of-date tradition, such as baking bread or brewing. Such reproductive (selfreproducing) activity is characteristic of the vast majority of entrepreneurs [6]. That is, focusing on promoting the product and getting the maximum profit.

- social business activity focused on the opinions and suggestions of its consumers. It is thought that social business has become simpler with the advent of advertising campaigns, promotion of product information, creation of social media sites. For example, comments on brand's social network page are beginning to influence companies' decisions: from price-making to working with staff. Accordingly, if in social entrepreneurship the request for social change is made by the company's CSR Department (Corporate Social Responsibility Department), then in social business model it depends on the audience [7].

- social entrepreneurship comes from charity, and social business originates from social media reputation. Social business solves the problems of its audience, no matter what the business is about, while social entrepreneurship creates projects for other social groups and for certain social issues. In other words, social business grows out of corporate account policies. It acts as a model of dialogue between managers, employees and customers of company`s CSR-department (Corporate Social Responsibility Department) [7].

The term "social business" was introduced for the first time by Nobel laureate Muhammad Yunus. Among the seven principles of social business described by Yunus there was to fight poverty, return on investment without dividends, ensure environmental awareness and improve working conditions. According to Yunus, social business should be the leading model of capitalism of the future with a human face. These seven principles look like entrepreneurial adaptation of the UN`s 17 principles of sustainable development.

Grameen Bank founded by Yunus himself can be considered as an example of a social business. This bank issued microloans to poor residents of Indian villages. It intended to transform the Olympic town after the Olympics, but not into the real estate for sale to wealthy people, on the contrary to homeless. A series of sneakers "Adidas" for people with musculoskeletal problems can also be considered as social business, as well as a batch of cheap vitaminized yogurt "Danone" for Asia, cheap mosquito nets made by BASF [7].

That is, one can immediately see the difference that these brands were not created from the very beginning by social enterprises, which solve an urgent issue and a national problem, but adapt to market demand and launch a one-time campaign to create a special product not on a permanent basis.

During the study of the concepts of "social entrepreneurship", "social business", "trend of social entrepreneurship in Ukraine" the authors analyzed the following studies: by Anna Gulevska-Chernysh "Social entrepreneurship is already actively developing in most countries. Are there any prospects in this area for Ukraine?" - prospects and opportunities for the development of social entrepreneurship in Ukraine; classification and opportunities for the development according to Vasyl Nazaruk (Head of the WNISEF Social Investment Program) - "5 great opportunities for the development of social entrepreneurship in Ukraine"; and the study of legal framework for the successful integration of social entrepreneurship.

Government support, involvement of professionals, public understanding, sufficient earnings, use of opportunities, access to investment are among six main 
indicators according to which at the end of October 2019 the Thomson Reuters Foundation in partnership with the corporate programme of Deutsche Bank's CSR Made For
Good Global made the ranking "The best country for social entrepreneurs in 2019" (Table 1).

Table 1 - TOP-10 countries for the development of social entrepreneurship in 2016 and 2019

\begin{tabular}{|c|c|c|c|}
\hline \multicolumn{2}{|c|}{2016} & \multicolumn{2}{|c|}{2019} \\
\hline \multicolumn{2}{|c|}{ place in the ranking } & \multicolumn{2}{|c|}{ place in the ranking } \\
\hline EU countries & Other countries of the world & EU countries & Other countries of the world \\
\hline $\begin{array}{l}\text { 1.France (3) } \\
\text { 2.Belgium (4) } \\
\text { 3. Denmark (6) } \\
\text { 4. Netherlands (7) } \\
\text { 5. Finland (8) }\end{array}$ & $\begin{array}{l}\text { 1.Canada (1) } \\
\text { 2.Australia (2) } \\
\text { 3.Singapore (5) } \\
\text { 4. Indonesia (9) } \\
\text { 5. Chile (10) }\end{array}$ & 1. France (10) & $\begin{array}{c}\text { 1.USA (1) } \\
\text { 2.Canada (2) } \\
\text { 3. United Kingdom (3) } \\
\text { 4. Singapore (4) } \\
\text { 5. Israel (5) } \\
\text { 6.Chile (6) } \\
\text { 7.South Korea (7) } \\
\text { 8. Hong Kong (8) } \\
\text { 9.Malaysia (9) }\end{array}$ \\
\hline
\end{tabular}

Source: grouped by authors according to data [8]

Analysis of the TOP-10 countries for the development of social entrepreneurship in 2016 and 2019 (Table 1). The situation in the countries was assessed by 664 experts from 44 countries. Top 10 are Canada, Australia, France, Belgium, Singapore, Denmark, the Netherlands, Finland, Indonesia, and Chile. Of our closest neighbours, Poland ranks 35th, Russia 23rd, and Turkey 42nd. Ukraine is outside the ranking, as it is compiled on the basis of 45 countries with the largest economies in the world in terms of GDP [8]. International ranking indicators are the important tool for the assessment of social entrepreneurship development in Ukraine. There are no unified statistics on the number of social enterprises in the world. EU indicators suggest 2.8 million social enterprises in the region. In the UK in 2018, there were 99,000 social enterprises, which employed 2 million people (5\% of the workforce) and contributed 60 billion pounds to the national GDP. More than half of the EU countries have adopted laws or national policies concerning the activities of social enterprises [8].

In Ukraine, only the Strategy for the Development of Small and Medium Enterprises for the period up to 2020 contains official mention of social entrepreneurship referring to the promotion of its development [9].
According to the catalog of social enterprises for 2016/2017 in Ukraine, there were 150 social enterprises having different organizational and legal forms from NGOs to LLCs. However, some experts believe that their number is much larger and can reach almost 1,000 companies. This difference is explained by the fact that not all companies were included into the catalog or not all of them met the requirements (for example, transparent reporting or annual reports dissemination) [10].

The lack of legal definition of social entrepreneurship, as well as state policy in this field is an obstacle for some social businesses aimed at market positioning and promotion of their activities. The Ukrainian situation is no exception, but the realities are different. Due to the lack of funds, the founders of social enterprises are often forced to work from one to three years on a voluntary basis in order to reach break-even point and be able to pay employees.

The All-Ukrainian Resource Center for the Development of Social Entrepreneurship "Social Initiatives" identified 5 major opportunities for the development of joint ventures in Ukraine (figure 1), which will encourage the boost of social enterprises [9].

availability of resources not involved in the activities of traditional enterprises

Figure 1. Opportunities for the development of social entrepreneurship in Ukraine

Source: Built by the authors on the basis [9]. 
Let us consider in more detail the potential opportunities that are the incentive to intensify the development of social entrepreneurship in the national economy:

1. opportunity - absence of the law that would regulate social entrepreneurship. It should be emphasized that it is not important whether there is such a form as a social enterprise, but it is important for what purpose the business is created. Here is another approach to business: we start a company not for benefits, but to improve the quality of life of vulnerable groups or communities;

2. opportunity - the availability of resources that are not involved in traditional business. For example: national minorities; elderly, youth, mothers with many children and others;

3. opportunity - big business is always interested in outsourcing. If a big business enters agrees to purchase the services supplied by a social enterprise for 1-2 years, the probability of bankruptcy of a joint venture decreases many times. The number of examples of such cooperation in Ukraine goes up.

4. opportunity - consumer loyalty to social enterprise products is rising (since there are few small businesses in Ukraine, social entrepreneurs can easily find their customers, form a more conscious culture of consumption, and thus jointly solve pressing social problems in communities).

5. opportunity - social entrepreneurship is supported by international foundations and organizations:

- support for internally displaced persons by the United Nations Development Programme. The aim of the programme is to create jobs for internally displaced persons in Ukraine, as well as for the local population of Donetsk and Luhansk regions;

- assistance to IDPs and communities affected by the conflict by the International Organization for Migration. One of the components of the programme is training and grants to IDPs to support their efforts through small businesses, self-employment and vocational training;

- almost all donor programmes aimed at rural development contain elements of social entrepreneurship (Monsanto Foundation, Heifer International Charitable Foundation);
- the Western NSI Enterprise Social Investment Programme, which is created to comprehensively support social enterprises through the provision of affordable credit lines, counseling and training services, and the establishment of social partnerships to address specific issues in communities.

Based on the above, we note that any type of activity can be called social, from the production of public goods to education and medicine services.

Current economic development demands regulatory framework and good conditions for the development of big businesses and SMEs in Ukraine. Of course, social enterprises will need specific bills, which also need to be implemented as soon as possible, because all over the world, social entrepreneurship is not a phenomenon, but a routine. Legal framework acts as the background for the flourishing business, supports equal opportunities for all social categories. This will immediately reduce unemployment, increase educational level, raise the level of medicine services, etc. The law is all that is needed for social entrepreneurship to flourish.

Social entrepreneurship is entrepreneurship based on general economic laws as well. The main task is to make them competitive and efficient. Social entrepreneurs need to adapt to general economic conditions.

\section{Conclusions}

Based on the study, we can conclude that Ukraine has chosen the right vector for solving social problems and has the opportunity to occupy relevant world ranks for social entrepreneurship. Nevertheless, the more problems it has the higher progress is waiting for it.

Every modern enterprise has its own social responsibility, which is the beginning of the integrated and developed way to create social entrepreneurship. The main algorithm of social entrepreneurship is to make a profit, but solving the problems of a society and assisting vulnerable groups without harm to business itself. In the context of deepening socio-economic problems, social entrepreneurship is to some extent an ideal business model.

\section{References}

1. Konovalova, M.V., Kharynina, O.M. (2016) Sotsialne pidpryiemstvo yak innovatsiinyi sposib vyrishennia sotsialnykh problem [Social enterprise as an innovative way of solving social problems]. Visnyk KamianetsPodilskoho natsionalnoho universytetu imeni Ivana Ohiienka. Ekonomichni nauky, № 11, S. 461-466. URL: http://nbuv.gov.ua/UJRN/vkpnuen_2016_11_64.[in Ukrainian].

2. Lunkina T. I., Ivanenko H. Yu. (2019) Osoblyvosti rozvytku sotsialnoho pidpryiemnytstva: zakordonnyi dosvid [Features of the development of social entrepreneurship: foreign experience]. Elektronne naukove fakhove vydannia z ekonomichnykh nauk «Modern Economics», № 5, S.142-147. URL : https://modecon.mnau.edu.ua. [in Ukrainian].

3. Kozhemiachenko, O.O., Solosich, O. S., Holub, M. O. (2018) Sotsialne pidpryiemnytstvo: svitovyi dosvid ta aspekty stanovlennia v Ukraini [Social entrepreneurship: world experience and aspects of becoming in Ukraine]. Suchasni problemy ekonomiky i pidpryiemnytstvo. № 21. S.140-149 [in Ukrainian].

4. Horishna, N.M. (2016) Fenomen sotsialnoho pidpryiemnytstva: sutnist i kryterii [The phenomenon of social entrepreneurship: essence and criteria]. Naukovyi Visnyk Uzhhorodskoho universytetu. Seriia: «Pedahohika. Sotsialna robota». Vypusk 2 (39). S. 58-61. [in Ukrainian].

5. Pryshchak, M. D., Lesko, O. Y. (2016) Psykholohiia upravlinnia v orhanizatsii [Management Psychology in Organization]. Vinnytsia: VNTU, 2016. 150 s. [in English]. 

6. HR,
Recruiting
Trends
in
South
Korea.
URL

https://pidru4niki.com/1267100562889/politekonomiya/pidpriyemnitstvo_vidi_pidpriyemstv. [in English].

7. Social business is one of the trends. URL : https://biggggidea.com/practices/1196/. [in English].

8. Social entrepreneurship: where the world and Ukraine are moving. URL : https://zn.ua/ukr/SOCIUM/socialnepidpriyemnictvo-kudi-ruhayutsya-svit-i-ukrayina-333573_html. [in English].

9. 5 great opportunities for the development of social entrepreneurship in Ukraine. URL : https://delo.ua/business/5-mozhlivostej-dlja-rozvitku-socialnogo-pidprijemnictva-v-ukraji-341252/. [in English].

10. Social Entrepreneurship: An Effective Tool for Overcoming Social Challenges in Ukraine? URL : https://socialbusiness.in.ua/knowledge_base/sotsial-ne-pidpryiemnytstvo-efektyvnyy-instrument-podolanniasotsial-nykh-vyklykiv-v-ukraini/ [in English]. 